\title{
State of Mind: History and the Narrative of Nationalism
}

\author{
Victoria Reil
}

Ours is a confusing world, with a cacophony of meanings, identities, and constructions vying for precedence in both individuals and the social structures in which they operate. Those perennial questions - what it means to be human, how one is distinct from others, and where one belongs in the seemingly infinite sea of humanity - have surely been asked since humankind developed the most primitive cognizance. History may be a means of approaching such questions, by putting individuals in the contexts of their own heritage. It provides a sense of continuity, locating conditions of our existence in time and perhaps offering explanation for why they are so. However, what precisely constitutes our heritage, where we belong in a historical sense, is up for debate.

Many have explored the possibility that common language, customs, and the historical ties which bring these commonalities about, bind us into groups or "nations." Language, artistic expression, and lifestyle unify such a people, communicating shared understanding and past experience in a manner that is beyond the grasp of outsiders. An ancient homeland fixed them in space and played a role in defining their national identity. If offered self-rule, a nation could protect its cultural integrity, produce laws that fit its unique value system, and generally regulate its own affairs with awareness of intricate context. Misunderstandings and hostilities could likewise cause chaos in multinational states, often to the oppression of minority nations.

This idea, gaining great popularity in the nineteenth century, left an enduring mark on intellectual activity, instigated revolutions and rebellions, and dictated both political structure and internal reform. The nation state became the ideal form of government. Having discovered themselves, nationalities would demand this autonomy or seek to consolidate national unity. The only problem is that, according to some recent scholarship, these nations as they understood themselves - objective units with ancient origins simply did not exist. Rather, opportunistic or deluded intellectuals borrowed from existing 
customs, languages, and historical legends to manufacture a modern identity and false history. This fictional identity would become a self-fulfilling prophecy as willing people were moulded into this national image through education, reform, and political activism. Nation-states were in fact political entities based on inventions from the minds of intellectuals, literally "states of mind".

Nationalism has been conceived in a variety of ways. Marxist historian Eric Hobsbawm ${ }^{1}$ asserted that nationalism was shaped by the bourgeoisie in order to preserve economic interests, ${ }^{2}$ and states and regimes intent on creating political unity. ${ }^{3} \mathrm{He}$ emphasized both the importance of advancements in society, technology and economy in making possible these national movements, ${ }^{4}$ and the novelty of national conditions and traditions as part of this modern construction. ${ }^{5}$ While Benedict Anderson, in his influential work Imagined Communities, agreed that nationalism was the product of a historical process, he examined the change in ideas, in addition to economy, as a critical factor in this development. ${ }^{6}$ Anderson's nationalism was not purely invented but rather formed itself by "misremembering the past."7 The idea that national identity was a modern creation was contested by Anthony D. Smith, who asserted that it was drawn from ancient ethnic identities similar to their product but without a political end. ${ }^{8}$ Although these scholars differed in their opinions of the source of nationalistic ideas, they all observed the role intellectuals played in constructing historical interpretation for political ends. ${ }^{9}$

It was precisely this issue that historian Patrick Geary stressed in The Myth of Nations. ${ }^{10}$ Geary asserted that modern history was founded upon nationalistic goals, and that because "official or quasi-official historians" obscure critical historical periods in order to support nationalistic priorities, history has become a "poisoned landscape." ${ }^{11}$ Guided by politically-motivated searches for national identity and territories of "primary acquisition," historians in Geary's estimation fed nationalistic claims in spite of the fact that "nothing in the historical record justifies them."12 He concluded that ethnicity (and, by extension, nationalism) could not be mapped because it "exists first and last in people's minds," with descendent political movements becoming dangerous and destructive forces "impervious to mere rational disproof." ${ }^{13}$ In order to evaluate this dismal assessment of history, an examination of nationalism, and its relationship with history, is needed. 
Many scholars agree that nationalism as it is known today has origins in the French Revolution. ${ }^{14}$ Even if ethnic identities, as Smith proposed, existed prior to the concept of nationalism, the state structure required to organize the dissemination of a common language and national awareness was definitely a modern invention. ${ }^{15}$ On a more pragmatic level, the French Revolution became an example to those wishing to attain political autonomy in the form of statehood. ${ }^{16}$ However, the concept of nationalism was to be refined by German romantics who described the nation as an organic and historical entity naturally defining all those living within it. ${ }^{17}$ Admission into a nation was contingent upon historical and ethnic connection. ${ }^{18}$ As this idea spread to Central and Eastern Europe, where state borders did not correspond with the aggregation of perceived nations, national movements became characterized by demands to shape political realities around nationalistic interests. ${ }^{19}$ The connection between shared ethnic history and statehood was further cemented following the First World War. During what Hobsbawm termed "the apogee of nationalism," nation-states proliferated under the Wilsonian principle of national self-determination. ${ }^{20}$ The eventual discovery that attempts to draw out complex ethnic borders could not satisfy all would-be nations, and the sobering connection between national interests of Nazi Germany and the ethnic cleansing of the holocaust, did not signal the end of nationalism. ${ }^{21}$ Scottish and Quebecois separatism, disputes over "homeland" in Palestine and Israel, and xenophobia in nations of Western Europe carry with them old assumptions of nationalism. ${ }^{22}$

For the purposes of this essay, nationalism will be defined as an ideology with two key assumptions: (1) that there exist primordial, objective nations defined by shared descent, history, customs, and language; and (2) that these nations have a right or a need for self-government in their conceived homeland, usually in the form of the modern state.

Nationalism is, according to this definition, a process of history in two ways. First, national identity is seen to be determined, in part, by a shared history which gives meaning to customs and draws a people together in a common narrative. ${ }^{23}$ Second, presentations of the fixed nature of a nation in history may be seen to legitimize claims for autonomy and continued possession of homeland. The historian, then, plays a key role in the conception and development of national awareness. 
Miroslav Hroch divided nationalist movements into three phases: In Phase A, a small group of intellectuals defines the nation. Phase B occurs when these ideas spread through "concerted agitation" among a small number of devotees. Finally, the apogee of Phase C, sees the mass adoption and advocacy of these nationalistic priorities. ${ }^{24}$ The historian is at the core of the movement, instigating and giving direction to nationalistic revolutionary activity. First, the identity of the nation is contingent upon its interpretation of history. "Communal history," wrote Smith, involving "foundation and liberation myths and [...] a cult of heroes" was used by intellectual-educators to explain "who we are, whence we came and why we are unique." 25 A nationalistic interpretation of the past provided a people with a sense of context and meaning, their own identity becoming woven into "a seamless, mythic entity [...] of history, religion, language, and customs." 26 National history, linking a people to its past, could then serve as a model for a supposed cultural restoration. Thus, the discovery of a Celtic "golden age" guided revolutionaries who used this history as a model of 'what was authentically 'ours' and therefore what 'we' must do to be 'ourselves' once again."27

Attempts at national re-creation are observed most clearly in the second task of the nationalist historian, identification of an ancient homeland to reclaim. German nationalists popularized the use of philology, the study of ancient languages, in order to trace back geographical heritage and determine early territory. ${ }^{28}$ This development has been paralleled by ethno-archaeology, which classifies artifacts based on "ethnic markers." 29 Scholars, in mapping this historical territory, are not simply engaging in disinterested research, but are drawing as well potential borders for nation-states, for, as Smith put it, a nation "needs before all else a national territory or homeland [which is] an historic home."30

Those historians contributing to national movements were distinctly forwardfacing: their research has very direct implications for the present day. Though, as Hroch noted, their initial audiences would be small groups of fellow-intellectuals, their work would eventually, if successful, feed a massive national movement. As such, presentation of their research was intended to spark nationalistic sentiments. Depictions of an ancestral homeland were "historical poetry" or a "modern romantic historiography," instilling a sense of rootedness and attachment in loyal patriots. ${ }^{31}$ The national history was presented 
as a "continuous narrative of national progress,"32 "the seamless connection between past, present and future." 33 The myth of national origin lacked only the final chapters, in which the motivated masses successfully achieve self-actualization in the form of statehood.

"History means interpretation," wrote E.H. Carr, "by and large, the historian will get the kinds of facts he wants." ${ }^{4}$ National history is no exception. Geary boldly asserted that “claims that 'we have always been a people' actually are appeals to become a people appeals not grounded in history but, rather, attempts to create history." 35 Smith is gentler in his judgement of intellectuals attempting to "undercut earlier definitions of the community," admitting to "selective readings of an ethnic past" though maintaining that the selection "can only take place within [...] pre-existing myths, symbols, customs and memories" of their communities. ${ }^{36}$ If the role of nationalist historians is indeed to find national continuity through history, they will be required to fit their findings into the narrative of national unity. Furthermore, when involved in creative processes such as advocacy for autonomy or novel definition of national language, the historian is involved in a sort of reversed research, projecting onto the future rather than probing the past.

We have examined, up to this point, the historian as a shaper in national movements. Yet is it not possible that these historians themselves are being shaped, directed, even blinded, by the dream of the nation? Does their engagement in current political movements limit or prohibit their essential "capacity to rise above the limited vision of [their] own situation," or is such a standpoint an inevitable consequence of the historian being a part of history, even a means of illuminating "the past [...] by insights into the problems of the present" ${ }^{37}$ Implicit in such questions is the purpose of history itself, and the extent to which academic disciplines should involve themselves in current affairs.

We shall begin in France, the birthplace of nationalism. France had for centuries been a unified monarchy, but this long history was interrupted by revolutionaries attempting to re-make their nation on the foundation of liberty, equality, and brotherhood. ${ }^{38}$ The metamorphic French Revolution and its aftermath were intended to "make a tabula rasa of the past," and many French historians of the nineteenth century rejected the idea that their Gaulish ancestors constituted a nation. ${ }^{39}$ Symbols of national unity such as the tricolore and La Marseillaise were unapologetically modern, inspired by a decided removal from past identity. ${ }^{40}$ Historian Jules Michelet was born into the aftermath 
of the French Revolution, and throughout his life witnessed manifold movements of fragmented agitators vying to redefine France after their own interests. ${ }^{41}$ At a time when, in the words of one historian, "the urge to reduce French diversity into unity [had] proven implausible," French historian Jules Michelet attempted to make sense of this protean and fractured past, and to reconcile the diversity of his nation into a unifying whole. ${ }^{42}$

In accomplishing this end, Michelet found the political, rational Western nationalism of the French Revolution insufficient. ${ }^{43}$ He readily adopted organic descriptions of the nation, with its myths of origin, attachment to homeland, and perception of enduring national solidarity. In his introduction to World History, he connected ancient territory to primeval, racial attributes, stating that "powerful local influences [...] make a man one with the land" and "the land is reflected in him." 44 The diverse races Michelet identified as the forbearers of the French nation, products of their environment, would in turn shape France. The democratic interests and eloquent prose of France were of Gaulish origin, the nation inherits a style of ingenuity from the South, and a love of history could be traced back to Flemish ancestors. ${ }^{45}$ As through the ages this diverse mix of peoples steeped, they attained a "marvelous unity" which allowed them to adopt principles of liberty and equality. ${ }^{46}$ Thus the French Revolution was not a grand departure from tradition, but a continued expression of enduring French spirit. Far from the citoyen who defines himself and his country, Michelet's child of France was a product of his climate and ancestry.

Michelet readily bent historical findings to his nationalistic ends, yet he was equally willing to shape himself according to them. The nation, he felt, was far more than a means to a political end, but a worthy cause in itself. Reflecting on his life's work, Michelet declared "beloved France [...] I worked for you." 47 He maintained that such a noble cause as his motherland justified subjectivity, even disregard for facts. ${ }^{48}$ However, the idea that France was a distinct entity, its own creature, even a religion, lent a form of self-conceived objectivity to his work. In an account bordering on mysticism, Michelet described his "discovery" of this personage: "A great light appeared, and I perceived France. [...] I was the first to perceive her as a soul and as a person." ${ }^{49}$ He would later address this being in a prayer of sorts, saying "you must take the place of God."50 Michelet, an unashamed nationalist historian, consciously fashioned his work after the image of the great, unified, historical nation he envisioned France to be. 
While France had pre-existing political autonomy and needed only a national character to enliven it, Czech historian Frantisek Palacky was involved in both the intellectual and political foundations of his nation. Bohemia had been part of vast empires and multinational states since the Middle Ages, and at the time of Palacky's birth had been in Habsburgian control for over four hundred years. ${ }^{51}$ However, a history of relative autonomy within the Habsburg Empire, an unsuccessful Hussite revolt engraved in the Bohemian memory, and flourishing interest in Czech language, music, and art in the eighteenth century, provided Palacky with ample material for a national revival. ${ }^{52}$

As a strong defender of Czech identity against German culture, it is ironic that Palacky was raised and educated in a German environment, and did not develop any attachment to his native language until his adolescence. ${ }^{53}$ In fact, it was likely during his studies at the Pressburg Grammar School, which has been described as "a small replica of Protestant German universities," that Palacky was introduced to the German idea of nationalism which would influence much of his work. ${ }^{54}$ Prior even to his selection of history as a means to study it, young Palacky aspired to somehow devote his life to the benefit of his country. ${ }^{55} \mathrm{He}$ would later rise to prominence as a Czech historian, heading such organizations as the Royal Bohemian Society of Sciences and the Matice česká, and being selected as the official historiographer of the Bohemian Estates. It was in this position that he was commissioned to write what would become his definitive work, a history of Bohemia..56 Unlike Michelet, Palacky had no desire to quietly support his nationalist cause from behind a desk. Rather, he involved himself directly in two of Bohemia's major political agitations. In the failed Revolution of 1848, he chaired the Slavonic Congress of Prague and helped draft two proposals for a revised Austrian constitution..$^{57}$ He returned to politics in the 1860s, becoming a member of the Imperial and Bohemian Diet and presiding over the National Party, helping in negotiations between the Czechs and Vienna. ${ }^{58}$ At Palacky's death in 1876, the Czechs "mourned him like a prince, or [...] like a father." Though he did not live to see the independence of his homeland, his scholarship and activism in promoting Czech nationhood led to his recognition as the "Father of the Nation."59

Palacky's work is characterized by the creation of a "nation myth," the eternal animosity he draws between Czechs and Germans, and the transparent political 
implications of his research. In a statement curiously similar to that of Michelet, a young Palacky promised that "my life and all my endeavours will be devoted to my country." 60 In his monumental History of the Czech Nation, he "defended [and] glorified the Czech past," 61 and consequently "the objectivity and scholarly detachment of his writing unquestionably suffered." $62 \mathrm{He}$ accepted the idea that the division of humanity into nations with distinctive characters and customs occurred "at the very beginning of the historical age," making the nation something of a timeless entity. ${ }^{63}$ Not only did he provide an explanation for the current circumstances of the Czech people based on their national character, but he justified their subjugation because of positive attributes he gave them. ${ }^{64}$ However, their most defining feature is perhaps the fact that they are not German, their history being "a ceaseless battle" with this "predatory nation."65 It is no surprise that Palacky considered the Hussite rebellion, a fierce Bohemian insurrection against Austrian Habsburg, to be the point at which "our nation reached the zenith of its historical importance."66 His history was more than a praise of his nation's virtues, as it also had unmistakable political undertones.

History of the Czech Nation was written for Palacky's own day. Much of it was completed after the 1848 defeat, during which time Palacky was under police surveillance. ${ }^{67}$ For all the German influences in Palacky's history, he clearly emulated the rhetoric of the French Revolution when he asserted that "freedom and equality of all citizens [...] were principle features of ancient Slav society." 68 If the history of the Czech nation was a Hegelian battle between Bohemians and Germans, its future could be not so much a synthesis as a long-needed separation between two irreconcilable entities.

The driving force behind Palacky's work was the idea that his Czech nation needed to go through a process of self-realization that could only be undertaken once the foreign Germanic element was removed. Unlike Michelet, Palacky did not consider national inspiration and glorification to be the end of his work; rather, the patriotic love his writing instilled in others was to result in political action. Without the assurance of pre-existing political protection, the nationalist intellectual's work changed, and success was achieved only with the realities of borders and governance. Palacky's freedom-loving Czech nation, as much as Michelet's unified France, was not so much a historical presence as a future for which he yearned. 
If the purpose of history is indeed, as Ranke proposed, to "show how it really happened," the national historians examined have done very poorly. ${ }^{69}$ Their presentation of the facts was selective and subjective, acceptable only when it depicted their respective nations according to their own perceptions. Their writings were successful not when they illuminate readers to the true conditions of the past, but when they sparked political action, feelings of unity and kinship, or even hatred towards opposing groups. On broader terms, distinction between past and present was blurred as nations attempt to create themselves based on these manipulated histories. Neither Michelet nor Palacky has provided an impartial, fact-based history because both prioritized national causes over objective research. Consequently, these historians have not enhanced understanding of the world or of individual identity, as both are contingent upon accurate rendition of the past.

It is possible, however, that history has a greater cause than strict representation. History could also become a means to further what Michelet has termed "a cause of right and truth."70 History as advocacy requires certain conclusions, and thus specific interpretations, which, as Carr argued, are "the lifeblood of history." ${ }^{11}$ It could be argued that, because historians must inevitably be selective with facts and present them according to some perspective, it makes little difference if they do so in a with an eye to a nationalistic end. Carr, however, has justly observed that "it does not follow that, because interpretation plays a necessary part in establishing the facts of history, and because no existing interpretation is wholly objective, one interpretation is as good as another."72 Though historians may never, has Carr has said, create a "wholly objective" interpretation, a flagrant sacrifice of facts on the altar of the national cause is a good way of ensuring that conclusions will be very distant from objectivity. ${ }^{73}$

Yet it is possible that nationalist historians, as with the rest of us, are not fully conscious of their own intentions. There are probably few, if any, scholars who have not at some time disregarded evidence which seems anomalous according to their present conceptions. Or, put another way, can nineteenth-century nationalist historians be evaluated based on what is known about nationalism in the twenty-first century? Indeed, these historians were influenced by strong currents of ideas about the nature of politics and humanity. However, to conclude that they, the victims of such ideologies, could not help but study history in the way they did, is to imply that the historian is incapable of 
stepping out of contemporary outlooks and examining the past on its own terms. "The historian who is most conscious of his own situation is also most capable of transcending it," wrote Carr. ${ }^{74}$ Paradoxically, such self-awareness necessary for historical research can be achieved by the study of history itself, insofar as it produces understanding of other ways of thinking, and of the influences shaping one's own perspective. Gaddis wrote that with empathy, and a mind open to the impressions of those studied, allow us to "view the past from its own perspective as well as our own."75 Firstly, this means that while studying history, one must be willing to entertain perspectives contrary to one's own. Secondly, by extension, this procedure can assist historians in seeing the present from these multiple perspectives. Although a perfect understanding of historical contexts, one's own and those of others, may not be accessible, such an understanding may be deepened through an empathetic and perceptive study of the past.

The nationalist historians were correct, then, in their assumption that a study of history is the key to greater understanding of oneself. The type of inquiry to attain such understanding, however, necessarily involves temporary suspension of one's own preconceptions, rather than marching forward determined to prove them. Instead of using history to justify political or social goals, or selecting and romanticizing a choice collection of information based on a fixed interpretation of the past, the historian must search the past for the comprehension to more wisely define such ends. Amidst the cacophony of opinions and questions, those who have truly acquainted themselves with the perspectives of the past may more readily make sense of the current world, and more readily distinguish reality from invention. 


\section{Notes}

${ }^{1}$ For more information on Hobsbawm and his theories, see Geoff Eley and Roland Grigor Suny, eds., Becoming National: A Reader (New York: Oxford University Press, 1996), 6; R.J.B. Bosworth, Nationalism, (Harlow, UK: Pearson Education, 2007), 32-33.

2 See E.J. Hobsbawm, Nations and Nationalism since 1780: Programme, Myth, Reality, 2nd ed. (Cambridge: Cambridge University Press, 1992), 23, 27-30, 39-40, in which Hobsbawm draws a connection with early nationalism and liberal economic thought; and ibid., 118-123, in which he further argues that later on, lowermiddle class employed linguistic nationalism to preserve their own economic interests above those of proletarian socialists.

${ }^{3}$ Hobsbawm, Nations and Nationalism, 90-91.

${ }^{4}$ As summarized in $i b i d ., 10$. The emergence of the state, and its need to organize and unify a loyal citizenry, is examined in ibid., 80-83. Ibid., 141-143 reviews the role of new modes of communication and national sport in bringing national sentiments to the masses, for example. Hobsbawm rejected the idea that national sentiment arose from historic consciousness; see ibid., 48-50.

${ }^{5}$ Eric Hobsbawm, "The Nation as Invented Tradition" in Nationalism, ed. John Hutchinson and Anthony D. Smith (Oxford: Oxford University Press, 1994), 76-83. Hobsbawm notes the artificial nature of national language, public ceremonies, and monuments in order to construct unity of newly-defined nations. See also Hobsbawm, Nations and Nationalism, 52-54, 9 for further argument on the construction of national language; and ibid., 63-65 for his assertion that the ethnic component to some national movements is subjective: "What united them was not blood but belief."

${ }^{6}$ See Benedict Anderson, "Imagined Communities" in Nationalism, ed. John Hutchinson and Anthony D. Smith (Oxford: Oxford University Press, 1994), 89. In specific, he attributes these changes to the loss of the following beliefs: (1) that certain forms of written language offered a fundamental connection to metaphysical truths, (2) that social stratification and monarchal rule were natural formations, and (3) that human history was intrinsically connected with cosmology. Note that he considers "print-capitalism" to be essential to the distribution of these ideas, if not their creation. ibid., 89-91.

${ }^{7}$ Eley and Suny, Becoming National, 241-242.

${ }^{8}$ Anthony D. Smith, "The Origins of Nations," in Becoming National, ed. Geoff Eley and Roland Grigor Suny (New York: Oxford University Press, 1996) 109-110. These ethnies, as Smith called them, had unifying memories and origin myths, historic territory, and a common culture - which could consist of language, customs, or religion - linking it to politicized nationalism in later centuries. Smith also argued that "in Europe, nations have been forming [...] from the medieval period" rather than being completely invented in the Modern Age.

${ }^{9}$ Hobsbawm wrote extensively on how "liberal bourgeoisie and their intellectuals" influenced the conceptualization of the nation, focusing particularly on economic theorists; see Nations and Nationalism, 2330, 102. He also noted the influence of intellectual elites in later movements. Ibid., 106-108, 110-112. In "The Nation as Invented Tradition," 76, he categorized national history as "suitably tailored discourse," i.e. fitted to the needs of the nationalistic movement. Anderson attributed colonial nationalism to bilingual intelligentsia and proposed that national communities are imagined reconstructions of "past, memory and imagination." Eley and Suny, Becoming National, 241-242. Even Smith acknowledged the influence of "a secularizing intelligentsia led by educator-intellectuals" in "rediscovery" or "recreat[ion]" of national past. Smith, "The Origins of Nations," 119.

10 Patrick J. Geary, The Myth of Nations: The Medieval Origins of Europe (New Jersey: Princeton University Press, 2002).

11 Ibid., 15, 7, 9, 11-12.

$12 \mathrm{Ibid} ., 37$. Geary wrote that although philology played an instrumental role in early nationalism, it often did not correspond to contemporary classifications. Ibid., 29-34, 37-38. Ethnoarchaeology, though employed to scientifically establish ancient territorial claims, was in fact based on disproven principles. Ibid., 34-35, 37-38. ${ }^{13}$ Ibid., 39-40.

${ }^{14}$ Historian R.J.B Bosworth wrote that the world has been involved in the identification of nations since the French Revolution, and dated such national symbols as the flag and anthem to the French Revolution.

Bosworth, Nationalism, 12, 25-27. Eley and Suny wrote that, for the "national awakening" of the nineteenth century, "the impact of the French Revolution [...] was paramount," and that the very idea of a state united by 
a common language, popular sovereignty, and eventually ethnic homogeneity, was a product thereof. Eley and Suny, Becoming National, 13, 19. Prasenjit Duara wrote that "the culmination of [the] conception of the nation was first seen in the French Revolution and exemplified in the idea of citizenship for all within the territory. Prasenjit Duara, "Historicizing National Identity, or Who Imagines What and When," in ibid., 158. Benedict Anderson likewise argued that a sense of national camaraderie based on "imagined community" took shape at the time of this revolution. Ibid., 24. "The French Revolution changed everything and nothing," asserted Geary, because although it did not initially embrace the idea that ethnicity was connected to rights of political autonomy, it accepted "the implicit assumption [...] that a shared cultural tradition [...] defined the French nation." Geary, The Myth of Nations, 22. Hobsbawm agreed that the connection between state, people, and territory emerged in conjunction with the French Revolution, though maintained that the idea of a preexisting people and associated territory was to come later. Hobsbawm, Nations and Nationalism, 18-19, 87. ${ }^{15}$ Hobsbawm's "characteristic modern state" was shaped during the French Revolution became the "supreme 'national agency'" over people within its territory, and employed mass education to instil nationalistic principles. Hobsbawm, Nations and Nationalism, 80, 91-94. Smith considered "unified territory, economy, mass education system and common legal rights as definitive traits of a nation. Smith, "The Origins of Nations," 107. Eley and Suny noted that "a fully developed national consciousness tends to require systematic propaganda or political education, normally but not invariably by a centralized state and its agencies," and that in France this did not take place until the Third Republic for this reason. Eley and Smith, Becoming National, 9.

16 See Eley and Suny, Becoming National, 13. Smith describes nationalism as a movement seeking for the conditions he listed above, implicit in statehood. Smith, "The Origin of Nations," 107-108.

${ }^{17}$ See Eley and Suny, Becoming National, 4-5; Geary, The Myth of Nations, 23; Hans Kohn, "Western and Eastern Nationalism" in Nationalism, ed. John Hutchinson and Anthony D. Smith (Oxford: Oxford University Press, 1994), 165. The work of German philosopher Johann Gottfried von Herder, would lay the foundation for this theory, stating in 1752 that "each nation has its own character." Herder, quoted in Bosworth, Nationalism, 70. His ideas would become very influential in nineteenth century national movements. See John Breuilly, "The Sources of Nationalist Ideology," in Nationalism, ed. John Hutchinson and Anthony D. Smith (Oxford: Oxford University Press, 1994), 104.

${ }^{18}$ See Smith, "The Origins of Nations," 107; Geary, The Myth of Nations, 33.

${ }^{19}$ See Kohn, "Western and Eastern Nationalism," 164.

20 See Hutchinson and Smith, Nationalism, 10; Bosworth, Nationalism, 108-110; Eley and Suny, Becoming National, 19-20; Hobsbawm, Nations and Nationalism, 131-133.

${ }^{21}$ Bosworth detailed the difficulties of several nations following the war in Nationalism, 113-116. Throughout Europe, he wrote, "everywhere freedom was circumscribed in the alleged interest of nationalism. [...] Minority groups were persecuted. [...] Behind the political events lay the structure of ethnic differences." In ibid., 111-112, he suggested that the idea of national self-determination seemed to justify the Jewish extermination. See also Hobsbawm, Nations and Nationalism, 134-135; Eley and Suny, Becoming National, 12. Hutchinson and Smith, Nationalism, 10-11.

22 See Geary, The Myth of Nations, 3-6; Bosworth, Nationalism, 199; Hobsbawm, Nations and Nationalism, 177; Hutchinson and Smith, Nationalism, 10-11.

${ }^{23}$ Eley and Suny wrote that aspects of national culture such as theatre, literature, popular festivals, or "invention of new rituals" such as "the commemoration of historical events" can be used to present a "myth of origin" or a nation-centred view of the past. Eley and Suny, Becoming National, 7-8. See also ibid., 27-28; Hobsbawm, "The Nation as Invented Tradition," 77-82; Duara, "Historicizing National Identity," 160. ${ }^{24}$ As summarized in Eley and Suny, Becoming National, 16. This idea would later influence Hobsbawm and Geary. See Hobsbawm, Nations and Nationalism, 11-12, 104; Geary, The Myth of Nations, 17-18.

25 Smith, "The Origins of Nations," 121.

${ }^{26}$ Smith, quoted in Eley and Suny, Becoming National, 5.

${ }^{27}$ Smith, "The Origins of Nations," 121.

${ }^{28}$ Geary, The Myth of Nations, 29-30.

${ }^{29}$ Ibid., 34-35.

${ }^{30}$ Smith, "The Origin of Nations," 120.

${ }^{31}$ Ibid. See also Bosworth, Nationalism, 14-15. 
32 Homi Bhabha, "Narrating the Nation," in Nationalism, ed. John Hutchinson and Anthony D. Smith (Oxford: Oxford University Press, 1994), 306.

33 Bosworth, Nationalism, 29.

34 E.H. Carr, What Is History? $2^{\text {nd }}$ ed. (Ontario: Penguin Books, 1990), 23. Note that Carr did not condemn the selective historian: "Any fact may, so to speak, be elevated to the status of a historical fact once its relevance and significance are discerned. [...] History is therefore a process of selection in terms of historical relevance." Ibid., 103, 105.

35 Geary, The Myth of Nations, 37.

36 Smith, "The Origins of Nations," 120.

${ }^{37}$ Carr, What Is History? 123, 36-37. Carr's own conclusion was that the capacity to see past oneself "is partly dependent on [one's] capacity to recognize the extent of [one's] involvement in that situation." Ibid., 123.

${ }^{38}$ See Jack Hayward, Fragmented France: Two Centuries of Disputed Identity (Oxford: Oxford University Press, 2007), 46.

${ }^{39}$ Ibid., 43, 45. The quote is from French anthem Internationale, the title of which alone suggests the French divergence from German principles of nationalism.

${ }^{40}$ See ibid., 43-44.

${ }^{41}$ In his childhood and adolescence he passed through the Napoleonic Era, studying in the Collége Charlemagne from 1812 to 1816 . At the age of 17 he experienced the death of his mother and the return of Louis XVIII's return to the throne. By the time of the 1830 Revolution he had completed his studies and was enjoying great success academically, having already published several works. His involvement in the February Revolution of 1848 led to the suspension of his course at the Collége de France, though it was restored to him later that year. He had published two volumes of his Histoire de la Révolution française the year prior to this revolution, and completed the third one year after. Michelet refused to swear allegiance to Louis-Napoleon following the coup-d'état of 1851, and so was dismissed from his professorship and exiled to Italy for two years. During the Franco-Prussian War, Michelet briefly returned to Italy. By the time of his death in 1874, he had completed over 40 major works and had witnessed an overwhelming variety of Frances. See See Lionel Gossman, "Preface," in Jules Michelet, On History, trans. Flora Kimmich, Lionel Gossman, and Edward K. Kaplan (Cambridge: Open Book Publishers, 2013), 19-22, ebrary e-book; Hayward, Fragmented France, 151-157.

${ }^{42}$ As one author summarized, French unity was "the dominant 'message' of the entire work [i.e. Michelet's multivolume history of France]"; Stephen Bann, The clothing of Clio: a study of the representation of history in nineteenth-century Britain and France (Cambridge: Cambridge University Press, 1986), 52, ACLS Humanities Ebook.

43 This description is according to the nationalism dichotomy of Hans Kohn. Eley and Suny, Becoming National, 4.

44 Ibid., 48, 26. In a later work he would write "As the fatherland, so is the man" ibid., 142. Thus the climate of Egypt and India kept indigenous residents from advancement, while Persian fecundity and lightness of air have the opposite effect, and the temperaments and physical attributes of Germans and Italians are products of their respective environments. Michelet, On History, 26-48.

45 Ibid., 53, 106-107.

46 Ibid., 57-58. Michelet asserted that by cause of this multi-racial solidarity, "France is not a race, [...] it is a nation." Ibid., 57.

47 Michelet, On History, 161.

${ }^{48}$ In his mind, the dilemma of sacrificing objectivity for nationalist ends did not even merit consideration. He encouraged the abandonment of the historian "chronicler of events" in favour of the "maker of meanings," and stated that good history was not written by those "assuming a stance of even-handedness" but was rather "written by practitioners who were committed to the cause of right and truth." Jules Michelet, quoted in Ceri Crossley, French Historians and Romanticism: Thierry, Guizot, the Saint-Simonians, Quinet, Michelet (New York: Routledge, 1993; Taylor and Francis e-Library, 2002), 185-186, ebrary e-book. More bluntly, he added that in writing "the true national history of a people [...] it matters little whether [the account] accords to the truth." Ibid., 194.

${ }^{49}$ Michelet, On History, 140. 
50 Full quote: "It is you that I shall turn to for my aid, my noble country. You must take the place of God who is escaping us and fill us with the incommensurable void which Christianity left when it died." Michelet, quoted in Crossley, French Historians and Romanticism, 198. The author described Michelet's perspective further: "the nation became the visible church of the religion of humanity." Ibid., 199.

51 In 1306 the Bohemians lost their last native king, and in 1526 Ferdinand I of Habsburg acquired it from Polish rulers. See R.J.W. Evans, Austria, Hungary, and the Habsburgs: Central Europe c. 1683-1867 (New York: Oxford University Press, 2006): 76-77.

${ }^{52}$ Ferdinand I's rule over Bohemia was characterized by "limited dominion," in which he consulted rather than supplanted local nobility, and under future rulers they were given great liberty with Bohemian administration, and were able to negotiate religious freedoms. Even after the Hussite rebellion of 1618-1620, these noble estates retained much of their control, as they would in coming centuries. Only during the reign of Metternich was this autonomy curtailed, so that in Palacky's day the nobility was Habsburgian. Ibid., 79, 8287, 94-97; Richard Georg Plaschka, "The Political Significance of Frantisk Palacky," Journal of Contemporary History 8, no. 3 (1973): 39. For cultural revival, see ibid., 63 (on theatre) 96 (on music), and 136 (on language).

53 See Monika Baár, Historians and Nationalism: East-Central Europe in the Nineteenth Century (New York: Oxford University Press, 2010), 29-30, ebrary e-book.

${ }^{54}$ J Pekar, "Fr. Palacky," Ceski casopis historicky, 1912, 215, quoted in Plaschka, "Political Significance," 36. See also ibid., 36-37 for an examination of nationalist influences in such an educational environment.

${ }_{55}$ Baár, Historians and Nationalism, 30-31. Other ambitions were to become a poet, a missionary, and a philosopher.

${ }^{56}$ See Ibid., 31-32.

${ }^{57}$ See Ibid., 32-33; Plaschka, "Political Significance," 49-50. The first draft proposed divisions similar to those already in existence, but the second divided the empire based on ethnolinguistic borders, significantly separating Germans from Slavs in Bohemia and Moravia. This latter proposal was rejected on the grounds that it was too radical, much to Palacky's dismay. Ibid. Evans argued that the very nationalistic ambitions of the 1848 Revolution were its downfall, as fragmented causes contested for dominance and chaos broke down the movement from within. Evans, Austria, Hungary, and the Habsburgs, 102.

58 See Baár, Historians and Nationalism, 33; Palacky, "Political Significance," 52.

59 Baár, Historians and Nationalism, 34.

60 Palacky, quoted in Plaschka, "Political Significance," 38.

$61 \mathrm{~J} \mathrm{Pekar}$, quoted in ibid., 41. Plaschka noted that Palacky conceived a "somewhat romanticized picture of the nation's emergence and mission." Ibid., 54.

62 Ibid., 53.

${ }^{63}$ Frantisek Palacky, "History of the Czech Nation in Bohemia and Moravia," in National Romanticism: The Formation of Nationalism, Balázs Trencsényi and Michal Kopecek, eds., Discourses of collective identity in Central and Southeast Europe (1770-1945), (Herndon, VA: Central European University Press, 2006), 53, 55, ebrary e-book.

${ }^{64}$ Ibid., 55. They did not have national unity, then, because they did not seek dominion. They were inflexible in their customs because they wanted equal rights and freedom for all. Delays in scholastic interest were due to their reluctance to seek privilege. Most importantly, they were unable to defend their territory because they were not "longing for conquest."

65 Palacky, quoted in Plaschka, "Political Significance," 45. This conflict would prove to be a recurring theme in Palacky's work. He wrote that he would through the course of the history "explain what phenomena became visible as a result of this ancient conflict and struggle in our country." Palacky, "History of the Czech Nation," 55.

${ }^{66}$ Palacky, "History of the Czech Nation," 55; see also Evans, Austria, Hungary, and the Habsburgs, 84-85.

${ }^{67}$ See Baár, Historians and Nationalism, 33.

${ }^{68}$ Palacky, "History of the Czech Nation," 54-55. Note that Palacky considered the Czech people to be from the "Slav group of nations." Plaschka, "Political Significance," 47.

${ }^{69}$ Leopold von Ranke, The Secret World of History: Selected Writings on the Art and Science of History, ed. and trans. Roger Wines (New York: Fordham University Press, 1981), para. 4.

${ }^{70}$ Michelet, quoted in Crossley, French Historians and Romanticism, 185.

${ }^{71}$ Carr, What Is History, 28. 
72 Ibid., 27.

${ }^{73}$ In the words of another historian regarding such advocacy: "The passion with which you make your case can, at times, overtake the patience needed to establish the case." John Lewis Gaddis, The Landscape of History (New York: Oxford University Press, 2004), 146.

${ }^{74}$ Carr, What Is History, 44.

${ }^{75}$ Gaddis, The Landscape of History, 124, 126. 


\section{Works Cited}

Anderson, Benedict. "Imagined Communities." In Nationalism, edited by John Hutchinson and Anthony D. Smith, 89-96. Oxford: Oxford University Press, 1994.

Bann, Stephen. The clothing of Clio: a study of the representation of history in nineteenthcentury Britain and France. Cambridge: Cambridge University Press, 1986. ACLS Humanities Ebook.

Baár, Monika. Historians and Nationalism: East-Central Europe in the Nineteenth Century. New York: Oxford University Press, 2010. Ebrary e-book.

Bhabha, Homi. "Narrating the Nation." In Nationalism, edited by John Hutchinson and Anthony D. Smith, 306-312. Oxford: Oxford University Press, 1994.

Bosworth, R.J.B. Nationalism. Harlow, UK: Pearson Education, 2007.

Breuilly John. "The Sources of Nationalist Ideology." In Nationalism, edited by John Hutchinson and Anthony D. Smith, 103-113. Oxford: Oxford University Press, 1994.

Carr, E.H. What Is History? 2 ${ }^{\text {nd }}$ ed. Ontario: Penguin Books, 1990. 
Crossley, Ceri. French Historians and Romanticism: Thierry, Guizot, the Saint-Simonians, Quinet, Michelet. New York: Routledge, 1993; Taylor and Francis e-Library, 2002). Ebrary e-book.

Duara, Prasenjit. "Historicizing National Identity, or Who Imagines What and When." In Becoming National: A Reader, edited by Geoff Eley and Roland Grigor Suny, 151-178. New York: Oxford University Press, 1996.

Eley, Geoff, and Roland Grigor Suny, eds. Becoming National: A Reader. New York: Oxford University Press, 1996.

Evans, R.J.W. Austria, Hungary, and the Habsburgs: Central Europe c. 1683-1867. New York: Oxford University Press, 2006.

Gaddis, John Lewis. The Landscape of History. New York: Oxford University Press, 2004.

Geary, Patrick J. The Myth of Nations: The Medieval Origins of Europe. New Jersey: Princeton University Press, 2002.

Hayward, Jack. Fragmented France: Two Centuries of Disputed Identity. Oxford: Oxford University Press, 2007. 
Hobsbawm, Eric. "The Nation as Invented Tradition." In Nationalism, edited by John Hutchinson and Anthony D. Smith, 76-83. Oxford: Oxford University Press, 1994.

-—- Nations and Nationalism since 1780: Programme, Myth, Reality. 2nd ed. Cambridge: Cambridge University Press, 1992.

Kohn, Hans. "Western and Eastern Nationalism." In Nationalism, edited by John Hutchinson and Anthony D. Smith, 162-165. Oxford: Oxford University Press, 1994.

Michelet, Jules. On History. Translated by Flora Kimmich, Lionel Gossman, and Edward K. Kaplan. Cambridge: Open Book Publishers, 2013. Ebrary e-book.

Palacky, Frantisek. "History of the Czech Nation in Bohemia and Moravia." In National Romanticism: The Formation of Nationalism, edited by Balázs Trencsényi and Michal Kopecek. Discourses of collective identity in Central and Southeast Europe (17701945). Herndon, VA: Central European University Press, 2006. Ebrary e-book.

Plaschka, Richard Georg. "The Political Significance of Frantisk Palacky." Journal of Contemporary History 8, no. 3 (1973): 35-55.

Ranke, Leopold von. The Secret World of History: Selected Writings on the Art and Science of History. Edited and translated by Roger Wines. New York: Fordham University Press, 1981. 
Smith, Anthony D. "The Origins of Nations." In Becoming National, edited by Geoff Eley and Ronald Grigor Suny. New York: Oxford University Press, 1996. 